\title{
PENGARUH PEMBERIAN AIR REBUSAN DAUN MINT TERHADAP FREKUENSI EMESIS PADA IBU HAMIL TRIMESTER I
}

\section{SISWI WULANDARI}

\author{
UNIVERSITAS KADIRI \\ Jl. Selomangleng No.1 Kec. Mojoroto, Kota Kediri \\ e-mail : wulandarisiswi@gmail.com \\ DOI : $10.35451 / j k k . v 3 i 1.501$
}

\begin{abstract}
Emesis in pregnancy is a condition where the mother experiences excessive nausea and vomiting. More than $70 \%$ of pregnant women suffer from this complaint in trimester 1 . Based on a preliminary study to 10 pregnant women with emesis, as many as $2(20 \%)$ pregnant women consume the drug to reduce nausea, and $8(80 \%)$ Still experiencing nausea. The purpose of the research is to know the influence of water-boiling mint leaves against emetic in pregnant women in the Sukorame Puskesmas in Kediri City. This research is preexperiment research with one group Pretest-posttest design. The population is the pregnant women trimester 1 in Sukorame Puskesmas and the sample in the study is all the pregnant women of TM 1 in Sukorame Puskesmas. The sampling techniques used the total population, with the instrument using an observation sheet. Based on the test Wilcoxon obtained a significant value of $p$ value $=0.001$, so it can be concluded that there is the influence of the waterboiling mint leaves to the emetic frequency in the 1st trimester pregnant women. Hope researchers can increase the participation to reduce the occurrence of emetic in pregnant women trimester 1 by consuming the water stew mint leaves.
\end{abstract}

Keywords: pregnant women trimester I, emesis, mint leaf

\section{PENDAhUlUAN}

Kehamilan merupakan proses berkesinambungan yang dimulai dari ovulasi, konsepsi, nidasi, implantasi dan proses embrio yang berkembang, yang berada di uterus kemudian menjadi aterm (Bobak, 2015). Kondisi tubuh yang dialami ibu selama kehamilan mengalmai perubahan pada organ tubuhnya yaitu adanya perubahan fisiologi, hal ini terjadi karena adanya perubahan hormonal dari dalam tubuh ibu. Adanya kadar hormone esterogen dan progesterone yang tidak seimbang di dalam tubuh membuat ibu dalam kondisi tidak nyaman, sehingga timbul keluhan yaitu muntah mual (Mandriwati, 2018; Smith R et al, 2018).
Angka kejadian Emesis yaitu $60-80 \%$ pada ibu primigravida dan $40 \%$ pada multigravida. Satu diantara seribu kehamilan, gejala-gejala ini bisa menjadi lebih berat (Suparyanti, 2016). Angka kematian ibu (AKI) di Indonesia yaitu 48/100.000 KH. Angka ini merupakan angkat palong tinggi di ASEAN. Angka kejadian di dunia adalah 515.000 jiwa setiap tahun (SDKI, 2017; Manuaba, 2015; WHO, 2018). Keluhan mual banyak dialami oleh ibu hamil. Namun, istilah untuk mual yang dirasakan pada pagi hari dialami sebanyak $50 \%$ wanita hamil (morning sicknes)merupakan kondisi yang tidak enak dalam kehamilan (Koesno $\mathrm{H}$, 2014). Pada trimester pertama 
kemungkinan besar wanita akan mengalami mual-mual dengan atau tanpa muntah. Gejala ini di mulai sekitar minggu keenam kehamilan dan biasanya menurun drastis di akhir trimester pertama (sekitar minggu ke-13) (Christodoulou SJ et al, 2018).

Perubahan saluran cerna dan adanya kadar hCG (Human Chorionic Gonadotropin) yang meningkat di dalam darah menyebabkan keluhan muntah dan mual yang kurang enak selama hamil (Jimenez S and Maria P, 2018). Nafsu makan pada ibu hamil yang menurun dikarenakan muntah mual yang berlebihan dapat mengganggu keseimbangan elektrolit tubuh dimana kadar kalsium, kalium dan natrium terganggu, sehingga berdampak pada proses metabolism tubuh (Neil AM and Nelson, 2019). Emesis gravidarum menyebabkan ibu muntah terus menerus tiap kali minum dan makan, sehingga ibu merasa lemah, pucat, dan frekuensi buang air kecil menurun drastis sehingga cairan tubuh berkurang dan darah menjadi kental (hemokonsentrasi) sehingga melambatkan peredaran darah yaitu oksigen dan jaringan sehingga dapat menimbulkan kerusakan jaringan yang dapat membahayakan kesehatan ibu dan perkembangan janin yang dikandungnya (Hidayati R, 2017).

Data dari penelitian Suwarni (2019) menunjukkan $66 \%$ wanita hamil TM 1 akan sering mengalami keluhan tersebut, terjadi pada $60-80 \%$ hamil pertama dan $40-60 \%$ hamil kedua atau lebih. Ada $12 \%$ emesis juga dialami ibu sampai akan melahirkan. Penelitian menunjukkan 50-90\% mual akan muncul pada TM 1, kemudian $25 \%$ bumil perlu istirahat dari pekerjaannya (Smith R et al, 2018).

Keluhan yang dialami ibu hamil berbeda-beda di setiap individu, ada yang merasa sangat mengganggu. Namun, ada juga yang biasa saja (Manuaba, 2015). Angka yang muncul, yaitu $80 \%$ muntah mual ringandialami TM 1 kehamilan dan $2 \%$ ibu perlu perawatan medis, karena keluhan mual muntah berat. Solusi untuk mengurangi perawatan medis, adalah dapat dengan diberikan terapi komplementer yang menggunakan tradisional dengan tanaman tumbuhan atau herbal, bisa dilakukan dan mudah didapatkan seperti daun peppermint, jahe, lemon, dan lain-lain (Booth T, 2018). Pemberian minuman rebusan daun mint sangat berpengaruh dalam mengatasi emesis. Peppermint (Daun Mint) juga diketahui dapat mengurangi keluhan muntah dan mual saat hamil (Elshabrina, 2019).

Peppermint atau permen Mint, minum teh atau dengan minyak Peppermint. Sebuah studi dari Wheeling Jesuit University,US, menyimpulkan kandungan minyak atsiri pada daun mint yang berguna untuk kelancaran system pencernaan dan mengatasi kejang yang kadang terjadi pada perut, yaitu kandungan menthol. Efek anastesi ringannya dan ditambah kandungan karminatif serta antispasmodik yang bekerja di usus halus pada saluran gastrointestinal (Tiran D, 2018).

Berdasarkan studi pendahuluan yang dilakukan oleh peneliti kepada $10 \mathrm{ibu}$ hamil yang berkunjung di Puskesmas Sukorame didapatkan $70 \%$ mengalami emesis. Dari hasil wawancara 7 ibu hamil mengalami atau merasakan mual dan atau tanpa muntah di pagi hari dengan frekuensi 5-7x dalam sehari selama 24 jam. 7 dari 10 ibu hamil mengatakan mengkonsumsi obat untuk mengurangi mual tapi masih merasakan mual dan belum ada satupun ibu hamil yang menggunakan daun mint untuk mengatasi emesis.

Berdasarkan penjabaran teori sebelumnya serta data yang disampaikan diperoleh rata-rata $60 \%$ mual dialami ibu hamil di awal. Mual dan muntah TM 1 yang terjadi masih diatasi dengan santai yaitu didiamkan saja, atau ada yang 
menggunakan obat (Koesno H, 2014). Solusi yang diharapkan adalah pengurangan penggunaan obat dan beralih ke terapi komplementer atau non faramkologis dulu. Tujuan penelitian yaitu untuk mengetahui pengaruh pemberian air rebusan daun mint terhadap emesis pada ibu hamil TM 1 di Puskesmas Sukorame Kota Kediri.

\section{METODE}

Rancangan penelitian adalah penelitian kuantitatif (Sugiono, 2011). Rancangan desain penelitian adalah pra eksperiment dengan one group pretestposttest design yang dilakukan di Puskesmas Sukorame Kota Kediri pada bulan Desember Tahun 2019. Pemberian intervensi air rebusan daun pada ibu hamil diberikan dengan dosis $1 \mathrm{sdt} /$ hari dan diminum 2 kali sehari diantara waktu makan.

Populasi dan sampel adalah keseluruhan ibu hamil Trimester 1 di Puskesmas Sukorame Kota Kediri. Teknik pengambilan sampling yang digunakan adalah total sampling. Sampel digunakan dalam penelitian berjumlah 12 responden. Variabel dalam penelitian ada dua, yaitu variable dependen (emesis) dan variable independen (pemberian rebusan daun mint). Analisis data yang digunakan yaitu analisis univariat dan bivariate.

Analisis bivariate dengan menggunakan Wilcoxon test untuk melihat pengaruh pemberian air rebusan daun mint terhadap emesis pada ibu hamil trimester pertama. Instrumen pengumpulan data yang digunakan adalah kuesioner tentang emesis, seperti frekuensi emesis sebelum dan sesudah diberikan intervensi.

Etika dalam penelitian yaitu sebelum dilakukan penelitian, peneliti menyampaikan penjelasan, dan memberikan lembar informed consent untuk ditandatangani oleh responden

\section{HASIL}

Tabel 1. Distribusi Frekuensi Karakteristik Responden Menurut Usia

\begin{tabular}{ccc}
\hline Usia & $\begin{array}{c}\text { Frekuensi } \\
(\mathrm{f})\end{array}$ & $\begin{array}{c}\text { Prosentase } \\
(\%)\end{array}$ \\
\hline$<20$ tahun & 4 & 33.00 \\
$20-35$ tahun & 8 & 67.00 \\
$>35$ tahun & 0 & 0 \\
\hline Total & 12 & 100 \\
\hline Sumber: Data Penelitian 2019
\end{tabular}

Berdasarkan tabel 1 dapat diinterpretasikan bahwa sebagian besar responden memiliki kategori usia 20-35 tahun yaitu 8 (67\%) responden. Sedangkan, tidak ada responden yang berusia lebih dari 35 tahun.

Tabel 2. Distribusi Frekuensi Karakteristik Responden Menurut Pendidikan

\begin{tabular}{lcc}
\hline \multicolumn{1}{c}{ Pendidikan } & $\begin{array}{c}\text { Frekuensi } \\
\text { (f) }\end{array}$ & $\begin{array}{c}\text { Prosentase } \\
(\%)\end{array}$ \\
\hline Dasar (SD-SMP) & 1 & 8.00 \\
Menengah (SMA) & 7 & 59.00 \\
Tinggi (D3 - PT) & 4 & 33.00 \\
\hline Total & 12 & 100
\end{tabular}

Sumber : Data Penelitian 2019

Berdasarkan tabel 2 dapat diinterpretasikan bahwa sebagian besar responden memiliki kategori pendidikan menengah (SMA) yaitu 7 (59\%) responden. Sedangkan, paling sedikit responden dalam kategori pendidikan dasar (SD-SMP), yaitu 1 (8\%) responden.

Tabel 3. Distribusi Frekuensi Karakteristik Responden Menurut Pekerjaan

\begin{tabular}{lcc}
\hline Pekerjaan & $\begin{array}{c}\text { Frekuensi } \\
(\mathrm{f})\end{array}$ & $\begin{array}{c}\text { Prosentase } \\
(\%)\end{array}$ \\
\hline PNS & 2 & 17.00 \\
Wiraswasta & 4 & 33.00 \\
IRT & 3 & 25.00 \\
Karyawan & 3 & 25.00 \\
Petani & 0 & 0 \\
\hline \multicolumn{1}{c}{ Total } & 12 & 100 \\
\hline
\end{tabular}

Sumber : Data Penelitian 2019 
Berdasarkan tabel 3 dapat diinterpretasikan bahwa sebagian besar responden memiliki kategori wiraswasta yaitu 4 (33\%) responden. Sedangkan, tidak ada responden petani.

Tabel 4. Distribusi Frekuensi Karakteristik Responden Menurut Usia Kehamilan

\begin{tabular}{ccc}
\hline $\begin{array}{c}\text { Usia } \\
\text { Kehamilan }\end{array}$ & $\begin{array}{c}\text { Frekuensi } \\
(\mathrm{f})\end{array}$ & $\begin{array}{c}\text { Prosentase } \\
(\%)\end{array}$ \\
\hline 1-4 minggu & 7 & 58.00 \\
5-8 minggu & 3 & 25.00 \\
9-12 minggu & 2 & 17.00 \\
\hline Total & 12 & 100 \\
\hline Sumber : Data Penelitian 2019
\end{tabular}

Berdasarkan tabel 4 dapat diinterpretasikan kebanyakan responden memiliki kategori usia kehamilan 1-4 minggu yaitu 7 (58\%) responden. Sedangkan, paling sedikit responden dalam kategori usia kehamilan 9-12 minggu, yaitu $2(17 \%)$ responden.

Tabel 5. Distribusi Silang Frekuensi Mual Muntah Sebelum dan Sesudah Diberikan

Air Rebusan Daun Mint Pada Ibu Hamil

Trimester 1 di Puskesmas Sukorame Kota Kediri Tahun 2019

\begin{tabular}{|c|c|c|c|c|}
\hline \multirow{3}{*}{ Emesis } & \multicolumn{4}{|c|}{$\begin{array}{l}\text { Kelompok Pemberian } \\
\text { Air Rebusan Daun Mint }\end{array}$} \\
\hline & \multicolumn{2}{|c|}{$\begin{array}{c}\text { Pre } \\
\text { Intervensi }\end{array}$} & \multicolumn{2}{|c|}{$\begin{array}{c}\text { Post } \\
\text { Intervensi }\end{array}$} \\
\hline & $\begin{array}{r}\text { Freku } \\
\text { ensi }\end{array}$ & $\begin{array}{l}\text { Perce } \\
\text { nt }\end{array}$ & $\begin{array}{r}\text { Freku } \\
\text { ensi }\end{array}$ & $\begin{array}{l}\text { Perce } \\
\text { nt }\end{array}$ \\
\hline Ringan ( $<10$ kali) & 2 & 17,00 & 6 & 50,00 \\
\hline Sedang (10 kali) & 3 & 25,00 & 3 & 25,00 \\
\hline Berat (Koma) & 7 & 58,00 & 3 & 25,00 \\
\hline Total & 12 & 100 & 12 & 100 \\
\hline Negative rank : 0 & Ties & \multirow{2}{*}{\multicolumn{3}{|c|}{$\begin{array}{l}\text { P Value }=0.001(a: \\
0.05)\end{array}$}} \\
\hline Positive rank : 7 & $: 5$ & & & \\
\hline
\end{tabular}

Sumber : Data Penelitian 2019

Berdasarkan tabel 5 dapat diinterpretasikan bahwa pada kelompok sebelum dilakukan pemberian air rebusan daunmint sebanyak 7 responden $(58,00 \%)$ mengalami emesis berat (koma). Namun, setelah dilakukan pemberian air rebusan daun mint, responden dengan kategori emesis berat berkurang menjadi 3 responden
$(25,00 \%)$, dan responden dengan emesis ringan meningkat menjadi 6 repsonden $(50,00 \%)$.

\section{PEMBAHASAN}

Emesis muncul karena asam lambung yang mengalami peningkatan dikarenakan hormon esterogen yang produktif di awal kehamilan. Rasa mual yang timbul bisa dikarenakan kondisi perut yang tidak diisi sehingga asam lambung terproduksi dan juga didukung adanya hCG (Human Chorionic Gonadotropin) yang berasal dari plasenta (Elshabrina, 2019).

Janin di dalam tubuh ibu memperoleh sirkulasi dan makanan dari plasenta. Pada saat ini biasanya emesis akan berhenti. Adapun dampak mikro dari emesis pada ibu hamil itu sendiri dapat menyebabkan lemas. Janin sulit berkembang karena kekurangan asupan nutrisi., sedangkan dampak makro bisa menyebabkan keguguran pada kehamilan (farrer $\mathrm{H}, 2016$ ).

Dalam proses kehamilan, emesis hal normal. Kejadian $70 \%$ keluhan tersebut pada TM 1 pada derajat ringan sampai berat. Pada bulan ke-4 hamil, keluhan ini berangsur-angsur akan menghilang. Apabila keluhan tidak menghilang maka akan muncul dehidrasi disertai berat badan menurun, sehingga mengganggu aktivitas sehari-hari (Surinah, 2018).

Penelitian Afriyanti (2017) sesuai dengan penelitian yang dilakukan, yaitu menunjukkan bahwa hasil uji $t$ test penelitian mendapatkan angka rerata frekuensi muntah sebelum mengkon sumsi daun mint 5.29 kali sehari dan sesudah mengkonsumsi sebesar 3.57 kali sehari. Hasil uji menunjukkan terdapat pengaruh konsumsi daunt mint terhadap frekuensi mual muntah ibu hamil trimester pertama dengan emesis gravidarum. Selain itu, penelitian Sumarni (2019) menunjukkan bahwa pemberian daun 
mint sangat efektif, dimana nilai $p$ signifikan yaitu $p=0.000$.

Berdasarkan data

dapat

diinterpretasikan bahwa nilai pre-test sebagian besar mengalami mual muntah yang berat dan tidak pernah meminum air rebusan daun mint saat mengalami emesis, hal ini dapat dipengaruhi oleh pendidikan ibu bahwa paling banyak berpendidikan menengah (SMA) sehingga dalam pengetahuan tentang hal tersebut juga masih sangat rendah, ibu tidak tahu tentang manfaat mengkonsumsi air rebusan daun mint dalam menurunkan ketidaknyamanan pada saat hamil termasuk saat mengalami emesis. Sedangkan, nilai post-test setengah responden mengalami mual muntah yang ringan hal ini dipengaruhi oleh pengetahuan ibu, dengan dilakukan penjelasan tentang manfaat air rebusan daun mint dan diberikan untuk diminum ibu dapat memahami manfaat daun mint untuk mengurangi emesis saat hamil, serta ibu dapat meminumya saat mengalami emesis gravidarum

Mint atau Mentha adalah herbal abadi kerabat labiate genus Mentha, ada banyak jenis spesies dari tumbuhan mint yang ada, dan yang paling umum adalah peppermint. Herbal ini, terutama bagian daunnya sangat banyak digunakan sebagai bahan makan atau penghias hidangan. Dan yang paling banyak pemanfaatannya adalah dari kandungan minyaknya, sebagai bahan dasar atau campuran obat (Alyamaniyah U, 2018).

Daun mint terdiri terutama dari air, serat, protein abu, dan karbohidrat, kandungan berlimpah mineral seperti yang terdapat dalam persentase tinggi, kalsium, kalium, magnesium, tembaga, mangan, natrium dan fosfor. Berkenaan dengan vitamin yang terdapat pada daun mint adalah vitamin kelompok $A, B, C$ dan $D$, daun mint juga sangat berlimpah asam amino seperti: arginin, asam aspartat, gluttamico, alanin, leusin, glisin, prolin, serin, dan valin dalam persentase yang sangat tinggi. Minyak esensial Mint diekstrak menjadi mentol, jenis alkohol yang disebut kiral ditemukan sekitar dua ribu tahun yang lalu di Jepang, yang terutama digunakan dalam penyusunan parfum dan obat-obatan (Parwitasari, 2018; Vivian, 2017).

Dari data hasil penelitian diatas dapat diketahui bahwa sebagian besar responden mengalami positive ranks yaitu terjadi perubahan tingkat emesis setelah diberikan air rebusan daun mint. Hal ini menunjukkan bahwa dengan dilakukan penjelasan tentang manfaat air rebusan daun mint dan cara minumnya, maka dapat meningkatkan pengetahuan ibu tentang manfaat daun mint untuk mengurangi emesis saat hamil, sehingga ibu dapat meminumya saat mengalami emesis gravidarum.

\section{KESIMPULAN}

Terdapat pengaruh pemberian air rebusan daun mint terhadap frekuensi emesis pada ibu hamil trimester pertama di Puskesmas Sukorame Kota Kediri, dengan nilai $p$ value $=0,001$. Harapan peneliti untuk responden yaitu dapat menambah pengetahuan responden tentang cara mengurangi rasa mual muntah pada kehamilan muda, yaitu salah satunya dengan menggunakan air rebusan daun mint.

\section{DAFTAR PUSTAKA}

Afriyanti D. 2017. Efektivitas Wedang Jahe dan Daun Mint Untuk Mengurangi Mual Muntah Pada Ibu Hamil di PMB YF Kota Bukittinggi. Jurnal Human Care. E-ISSN:2528-66510, Volume 2, No 3.

Alyamaniyah U. 2018. Efektivitas Pemberian Wedang Jahe Terhadap Penurunan Emesis Gravidarum Pada Trimester Pertama di Polindes Tebalo Manyor Gresik. http://www. academia.edu/8404812/UMMI HASANAH_ALYAMANIYAH_ 101211123037 
Bobak IM, Lowdermilk DL. 2015. Buku Ajar Keperawatan Maternitas Edisi 4. Jakarta: EGC.

Booth T. 2018. Tanya Jawab Seputar Kehamilan. Jakarta: Bhuana IImu Populer.

Christodoulou SJ, et al. 2018. Postraumatic stress symtoms following pregnancy complicated by hyperemesis gravidarum. The Journal of Maternal Fetal and Neonatal Medicine. Volume 2 (4).

Elshabrina. 2019. Dahsyatnya Daun Obat Sepanjang Masa. Yogyakarta: Cemerlang Publishing.

Farrer H. 2016. Keperawatan Maternitas. Edisi 4, Vol 2, Alih Bahasa: dr. Andry Hartono. Jakarta: EGC.

Hidayati R. 2017. Asuhan Keperawatan pada Kehamilan Fisiologis dan Patologis. Jakarta: Salemba Medika.

Jimenez S, Maria P. 2018. The Pregnant Woman'sComfort Guide ( $1^{\text {sted.). }}$ Jakarta: Arcan.

Koesno H. 2014. Standar Pelayanan Kebidanan. Jakarta: EGC.

Mandriwati GA. 2018. Penuntun Belajar Asuhan Kebidanan Ibu hamil. Jakarta: EGC.

Semina Nasional Sains, Teknologi dan Sosial Humaniora Universitas Indonesia Timur. Volume 1 (1).

Suparyanto. 2016. Konsep Emesis Gravidarum. Jakarta: EGC.

Surinah. 2018. Buku Pintar Kehamilan dan Persalinan. Jakarta: Gramedia Pustaka Utama.

Suwarni. 2019. Hubungan Karakteristik Ibu Hamil Trimester I Dengan Morning Sickness di Poliklinik
Manuaba CAI. 2015. Pengantar Kuliah Obstetri. Jakarta: EGC.

Manuaba. 2015. Ilmu Kebidanan Kandungan dan KB. Jakarta: EGC.

Neil AM and Nelson. 2019. Hyperemesis Gravidarum. Journal Obstetrics and Gynecology. Volume 5(2).

Parwitasari. $2018 . \quad$ Perbandingan Efektivitas Pemberian Rebusan Jahe Dan Daun Mint Terhadap Mual Muntah Pada Ibu Hamil. http://jom.unri.ac.id/ index.php/JOMPSIK/article/view/ $3476 / 0$

SDKI. 2017. Survei Demografi dan Kesehatan Indonesia. Jakarta.

Smith R John, et al. 2018. Mangement The Third Stage of Labor. Medscape reference. Available from : http://emedicine.medscape,com/ar ticle/275304-overview

Sugiono. 2011. Metode Penelitian Kuantitatif Kualitatif dan R\&D. Bandung: Alfabeta.

Sumarni, Rosita, dan Musdalifah. 2019. Efektivitas Pemberian Air Rebusan Jahe dan Daun Mint Terhadap Intensitas Mual Muntah Pada Ibu Hamil Trimester 1 di Puskesmas Dahlian Makassar. Buku Prosiding Kebidanan dan Penyakit Kandungan Badan Pelayanan Kesehatan RSU Dr. Zainoel Abidin Banda Aceh.

Tiran D. 2018. Mengatasi Mual-mual dan Gangguan Lain Selama Kehamilan. Jakarta: Disglossia.

Vivian. 2017. Asuhan Kehamilan untuk Kebidanan. Jakarta: Salemba Medika.

WHO. 2018. Maternal Mortality in 19902018. World Health Organization. 